\title{
Communication
}

\section{Aerobic Exercise Induces Alternative Splicing of Neurexins in Frontal Cortex}

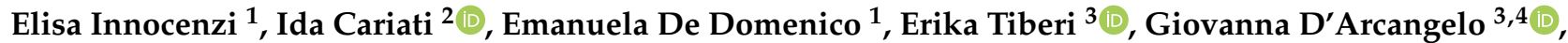 \\ Veronica Verdile 5,6 , Maria Paola Paronetto ${ }^{5,6} \oplus^{\circ}$, Virginia Tancredi ${ }^{3,4}, *\left(\mathbb{C}\right.$, Marco Barchi $^{1}{ }^{1}$, Pellegrino Rossi $^{1}$, \\ Claudio Sette ${ }^{6,7}$ and Paola Grimaldi $1,6, *$ (D)
}

\section{check for}

updates

Citation: Innocenzi, E.; Cariati, I.; De Domenico, E.; Tiberi, E.; D'Arcangelo,

G.; Verdile, V.; Paronetto, M.P.;

Tancredi, V.; Barchi, M.; Rossi, P.; et al Aerobic Exercise Induces Alternative Splicing of Neurexins in Frontal Cortex. J. Funct. Morphol. Kinesiol. 2021, 6, 48. https://doi.org/ $10.3390 /$ jfmk6020048

Academic Editor: Alessandro Castorina

Received: 21 April 2021

Accepted: 26 May 2021

Published: 31 May 2021

Publisher's Note: MDPI stays neutral with regard to jurisdictional claims in published maps and institutional affiliations.

Copyright: (c) 2021 by the authors Licensee MDPI, Basel, Switzerland. This article is an open access article distributed under the terms and conditions of the Creative Commons Attribution (CC BY) license (https:/ creativecommons.org/licenses/by/ $4.0 /)$
1 Department of Biomedicine and Prevention, "Tor Vergata" University of Rome, Via Montpellier 1, 00133 Rome, Italy; elisa.inno92@gmail.com (E.I.); emanuela.dedomenico@gmail.com (E.D.D.); marco.barchi@uniroma2.it (M.B.); pellegrino.rossi@med.uniroma2.it (P.R.)

2 Department of Clinical Sciences and Translational Medicine, "Tor Vergata" University of Rome, Via Montpellier 1, 00133 Rome, Italy; ida.cariati@uniroma2.it

3 Department of Systems Medicine, "Tor Vergata" University of Rome, Via Montpellier 1, 00133 Rome, Italy; erika_tiberi@libero.it (E.T.); giovanna.darcangelo@uniroma2.it (G.D.)

4 Centre of Space Bio-Medicine, “Tor Vergata" University of Rome, Via Montpellier 1, 00133 Rome, Italy

5 Department of Movement, Human and Health Sciences, University of Rome "Foro Italico", Via dei Robilant 1, 00135 Rome, Italy; veronica.ver@live.it (V.V.); mariapaola.paronetto@uniroma4.it (M.P.P.)

6 Laboratory of Cellular and Molecular Neurobiology, IRCCS Fondazione Santa Lucia,

Via del Fosso di Fiorano 64, 00143 Rome, Italy; claudio.sette@unicatt.it

7 Department of Neuroscience, Section of Human Anatomy, Catholic University of the Sacred Heart, Largo Francesco Vito 1, 00168 Rome, Italy

* Correspondence: tancredi@uniroma2.it (V.T.); p.grimaldi@med.uniroma2.it (P.G.)

Abstract: Aerobic exercise (AE) is known to produce beneficial effects on brain health by improving plasticity, connectivity, and cognitive functions, but the underlying molecular mechanisms are still limited. Neurexins (Nrxns) are a family of presynaptic cell adhesion molecules that are important in synapsis formation and maturation. In vertebrates, three-neurexin genes (NRXN1, NRXN2, and NRXN3) have been identified, each encoding for $\alpha$ and $\beta$ neurexins, from two independent promoters. Moreover, each Nrxns gene (1-3) has several alternative exons and produces many splice variants that bind to a large variety of postsynaptic ligands, playing a role in trans-synaptic specification, strength, and plasticity. In this study, we investigated the impact of a continuous progressive (CP) AE program on alternative splicing (AS) of Nrxns on two brain regions: frontal cortex (FC) and hippocampus. We showed that exercise promoted Nrxns1-3 AS at splice site 4 (SS4) both in $\alpha$ and $\beta$ isoforms, inducing a switch from exon-excluded isoforms (SS4-) to exon-included isoforms (SS4+) in FC but not in hippocampus. Additionally, we showed that the same AE program enhanced the expression level of other genes correlated with synaptic function and plasticity only in FC. Altogether, our findings demonstrated the positive effect of CP AE on FC in inducing molecular changes underlying synaptic plasticity and suggested that FC is possibly a more sensitive structure than hippocampus to show molecular changes.

Keywords: exercise; neurexins; frontal cortex; hippocampus; alternative splicing; synapsis

\section{Introduction}

\subsection{Beneficial Effects of Aerobic Exercise on Brain Health}

$\mathrm{AE}$ is known to produce beneficial effects on brain health [1-3] and is considered a potent neuroprotective factor $[4,5]$. In humans, sustained exercise has been clearly demonstrated to enhance learning and memory, improving executive function, and counteracting age-related mental decline [6,7]. Although the effects of physical activity on the brain are relatively widespread, there are specific regions that seem more sensitive than other brain areas. Notably, these regions are strongly associated with executive and cognitive 
functions and include hippocampus and FC. Previous studies in rodents have shown that exercise stimulates angiogenesis [8], increases the length and number of the dendritic interconnections between neurons [9], and stimulates neurogenesis and the circulation of important neurotrophic factors, such as brain-derived neurotrophic factor (BDNF) [10]. However, the molecular mechanisms underlying the relationship between AE and brain plasticity in different brain areas are still unknown.

\subsection{Role of Neurexins in Neuroplasticity}

Neuroplasticity refers to the brain's ability to modify its internal connections in response to external stimuli [11]. Changes in cortical neuron connectivity require modifications of synapse number and strength. At the molecular level, synapsis formation, maturation, and resolution are regulated by a network of adhesion molecules at presynaptic and postsynaptic sites. Among the best characterized molecules, there are NRXNs, which work as important organizers of synapses [12-14]. In both mice and humans, NRXNs are encoded by three genes (Nrxn1, Nrxn2, and Nrxn3), each encoding for a larger alpha $(\alpha)$ and a shorter beta $(\beta)$ isoform from alternative promoters $[15,16]$. Further complexity in the NRXN repertoire is achieved through AS regulation of both types of isoforms, thus yielding over thousand different splice variants [17]. AS of pre-mRNAs is ubiquitous in the eukaryotic genome and its importance in brain has recently received a great attention $[18,19]$. However, the molecular mechanisms that generate splice variants, the potential function of different protein isoforms and what conditions regulate their expression in the nervous system, are not well characterized. All $\alpha$-NRXNs are alternatively spliced at six sites, referred to as SS 1 to 6 whereas the shorter $\beta$-NRXNs contain only SS\#4 and 5 [20]. The resulting splice variants can bind a large variety of postsynaptic ligands, playing a role in trans-synaptic specification, plasticity, and strength. AS of the SS4 segment is highly conserved in all Nrxn pre-mRNAs and incorporation of the SS4 exon generates SS4+ variants, containing a 30 amino acid insertion, whereas skipping of the SS4 exon results in the SS4- variants. The presence or absence of this exon determines binding of NRXNs to different post-synaptic molecules [21-28], contributing to differentiation, plasticity, specificity of synapses, and behavioral features $[29,30]$. In vertebrates, NRXNs are synthesized throughout the brain in all excitatory and inhibitory neurons [31,32] and display differential expression patterns, with the abundance of $\alpha \mathrm{Nrxns}$ exceeding that of $\beta N r x n$ [31]. Some studies based on single cell RT-PCR and RNA-Seq have revealed cell type-specific Nrxn expression and distinct expression of Nrxn mRNA splice variants in a given cell $[17,33,34]$. The expressions are modulated by diurnal cycle [35], during development [36], by neurotrophins (NTs) and neuronal activity [37,38], or in response to fear conditioning [39] and to environmental experience such as chronic cocaine treatment [40].

The aim of the present study was to investigate the effects of $\mathrm{CP} A \mathrm{AE}$ on molecular changes underlying synaptic plasticity in mouse hippocampus and FC, by studying the alternative splicing of Nrxn1-3.

\section{Materials and Methods}

\subsection{Animal Care and Ethics Statement}

All animal breeding, maintenance, and research protocol were performed as described in the project approved by the Ethics Committee of the Interdepartmental Service CentreStation for Animal Technology (STA)-University of Rome "Tor Vergata" and in accordance with national and international laws and policies (Directive 2010/63/EU of the European Parliament and of the Council, Italian Legislative Decree 26/2014). C57BL/6N mice, provided by the STA (Charles River, Calco, Milan, Italy, RRID:MGI:5656552), were randomly assigned and housed in standard clear plastic cages and kept in light/dark cycle of 12:12 $\mathrm{h}$ and ventilation of 10-20 times/h, with ad libitum water and food. Mice were kept in social groups at a constant temperature of $20 \pm 2{ }^{\circ} \mathrm{C}$ and relative humidity of $50 \pm 10 \%$. A block randomization method was used to randomize subjects into groups resulting in equal 
sample sizes. All efforts were made to minimize the number of animals used and to reduce their suffering.

\subsection{Training System and Schedule}

The new Rotarod 47600 (Ugo Basile, Italy) was used for the training. A total of 10 C57BL/6N male mice were divided into 2 groups: one control sedentary group and one group submitted to $\mathrm{CP}$ training program, as previously reported [41,42]. CP program was based on incremental speed changes with gradually increasing intensity of the exercise. It was characterized by three periods: an initial period with a slow rhythm, an intermediate period with a slightly faster pace, and a final period at a fast pace. The speed of the revolutions per minute (RPM) increased gradually starting from a speed of 10 RPM to $32 \mathrm{RPM}$, without any interruption, with a total of $18 \mathrm{~min}$ of training. The mice started CP training at the age of 30 days post-partum (dpp) (P30) and exercise was carried out three times a week for a total of 12 weeks, ending at the age of $120 \mathrm{dpp}$ (P120) (Figure 1A,B). The sample size was arbitrarily set to 10 with 5 animals each, randomly selected.

\subsection{Animals Assessment}

Animal weight was checked throughout the training protocols (before, during, and at the end of the session). According to conventional procedures [42], all mice were subjected to two different tests to evaluate their physical performance. The strength test was performed using a force transducer (AD Instruments, Ltd., Sydney, Australia; cat. no. MLT050/D). Briefly, the mice were suspended by front limbs while posterior limbs were immobilized. The transduced force was connected to a Lab Chart software program (AD Instruments) for data recording and analysis. The time between the start of the test and the fall was measured. Each mouse performed this test before the training and after the last training session. Sedentary mice performed the same test. Every test consisted in three trials for each animal. Resistance was evaluated using RotaRod at a constant speed of 10 RPM and counting the falls number/time for each training session. The "time limit" was considered as the time between the start of the test and the occurrence of the third fall. If no falls occurred, the test was stopped after $30 \mathrm{~min}$. The first week of exercise of trained mice was characterized by the same number of falls of sedentary mice and, therefore, was considered as a control condition.

\subsection{RT-PCR Analysis and Quantitative Real-Time PCR}

At the end of the training period, all mice were sacrificed according to conventional procedures under anesthesia with halothane (2-Brom-2-chlor-1,1,1-trifluor-ethan). Brains were quickly removed, and hippocampus and FC were dissected and suspended in Triazol reagent (Invitrogen). Similarly, muscle tissues were collected from quadriceps and suspended in Triazol reagent. FC was extracted at different post-natal ages: P30, P75, P120, and P12M (months). Total RNA was extracted from isolated tissues and $1 \mu \mathrm{g}$ was used for retro transcription (RT) using M-MLV reverse transcriptase (Invitrogen). cDNA was used as template for semiquantitative PCR (RT-PCR) analysis (GoTaq, Promega) or quantitative real-time PCR (qPCR) analysis using PowerUp SYBR Green Master Mix (Applied Biosystems) and Applied Biosystems StepOnePlus Real-Time PCR system (Applied Biosystems) according to the manufacturer's instructions. All the primers used are listed in Table 1.

\subsection{Statistical Analysis}

GraphPad Prism v 8.4.2 was used to plot all graphs and to perform all statistical analysis. For two-group comparison, unpaired, two-tailed Student's $t$-test was used to determine the differences between the groups. Ordinary one-way ANOVA (ANalysis Of VAriance) was used to determine the differences between multiple groups; $p<0.05\left(^{*}\right)$, $p<0.01\left(^{* *}\right), p<0.001\left(^{* * *}\right)$, and $p<0.0001\left(^{* * * *}\right)$ were considered to be significant. 
A

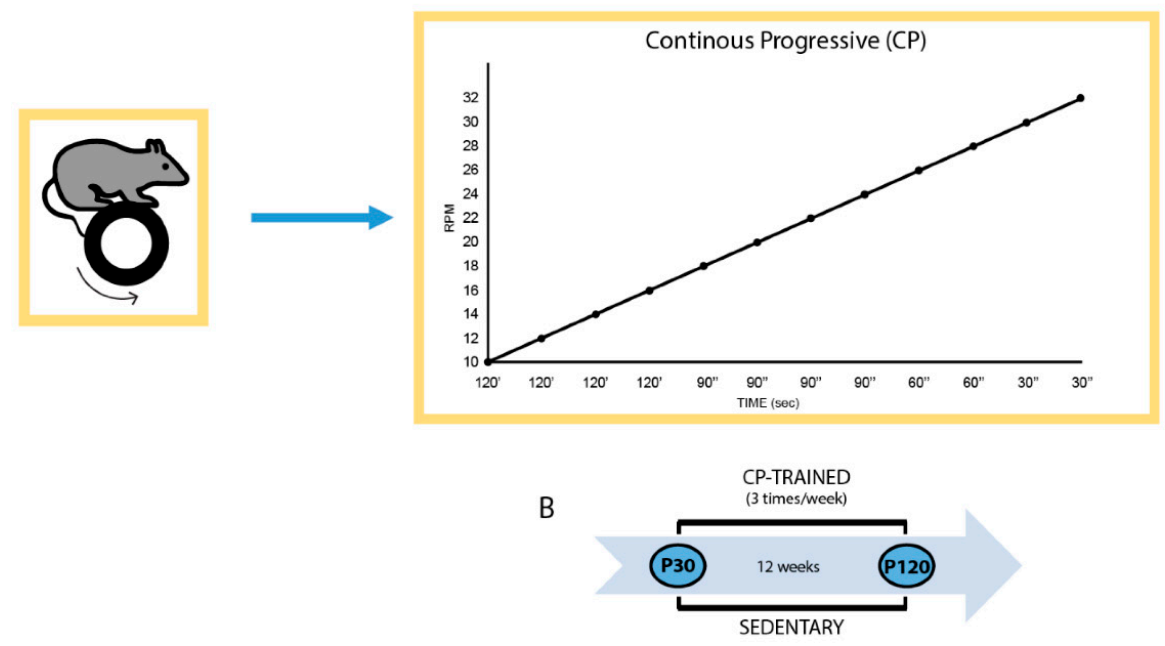

C
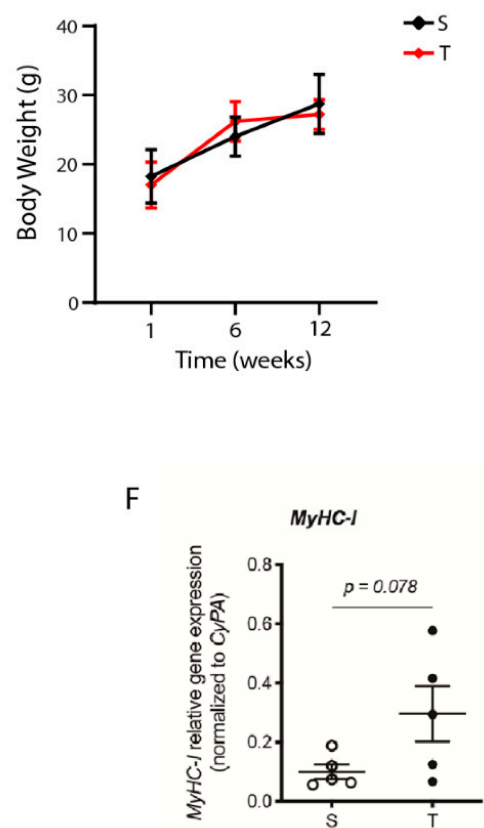

H

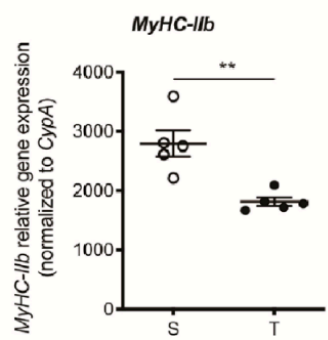

D

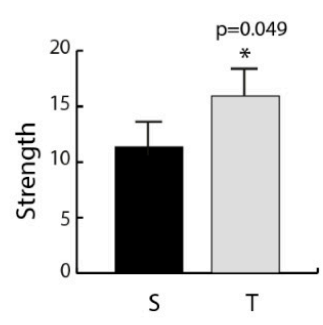

G
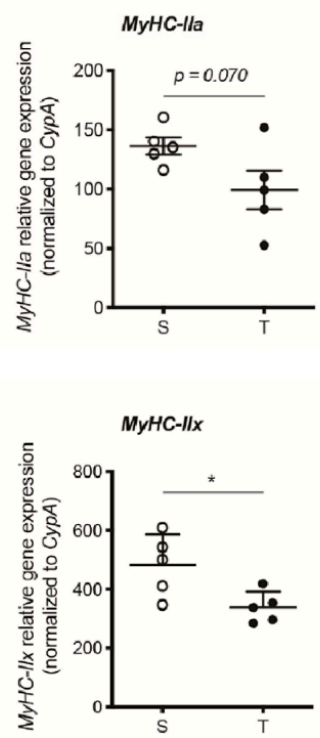

Figure 1. Continuous progressive (CP) aerobic exercise (AE) promotes physical performance and affects muscle fiber expression. (A) Schematic representation of CP exercise: CP program was carried out three times a week for a total time of 12 weeks. The training schedule is reported: $120^{\prime \prime}$ at 10 RPM, 120" at 12 RPM, 120" at 14 RPM, 120" at 16 RPM, 90" at 18 RPM, 
90" at 20 RPM, 90" at 22 RPM, 90" at 24 RPM, 90" at 26 RPM, 60" at 28 RPM, 60" at 30 RPM, and 30" at 32 RPM. (B) Timeline of the training program. (C) Body weight of sedentary and trained mice at the end of exercise. (D) Histogram reporting the strength evaluated at the end of exercise, through a test using a force transducer as reported in materials and methods. (E) Histogram reporting resistance as number of falls in trained and sedentary mice. Resistance was evaluated by a test on the RotaRod at constant speed of 10 RPM considering the falls number/time (CP: 1st week $12.3 \pm 9.1$, 6th week 3.2 \pm 3.6 , and 12th week $2.0 \pm 2.8$ ). ${ }^{*} p<0.05$. Error bars represent SD. (F-I) Relative expression of MyHC isoforms of quadriceps muscles from sedentary (S) and trained (T) mice. RT-qPCR analysis shows the expression levels (normalized to CyPA) of MyHC-I, MyHC-IIa, MyHC-IIb, and MyHC-IIx, in S e T mice. Statistical analysis was performed by unpaired Student's $t$-test and two-way ANOVA $\left({ }^{*} p<0.05 ;{ }^{* *} p<0.01\right)$.

Table 1. List of primers.

\section{RT-PCR Nrxns}

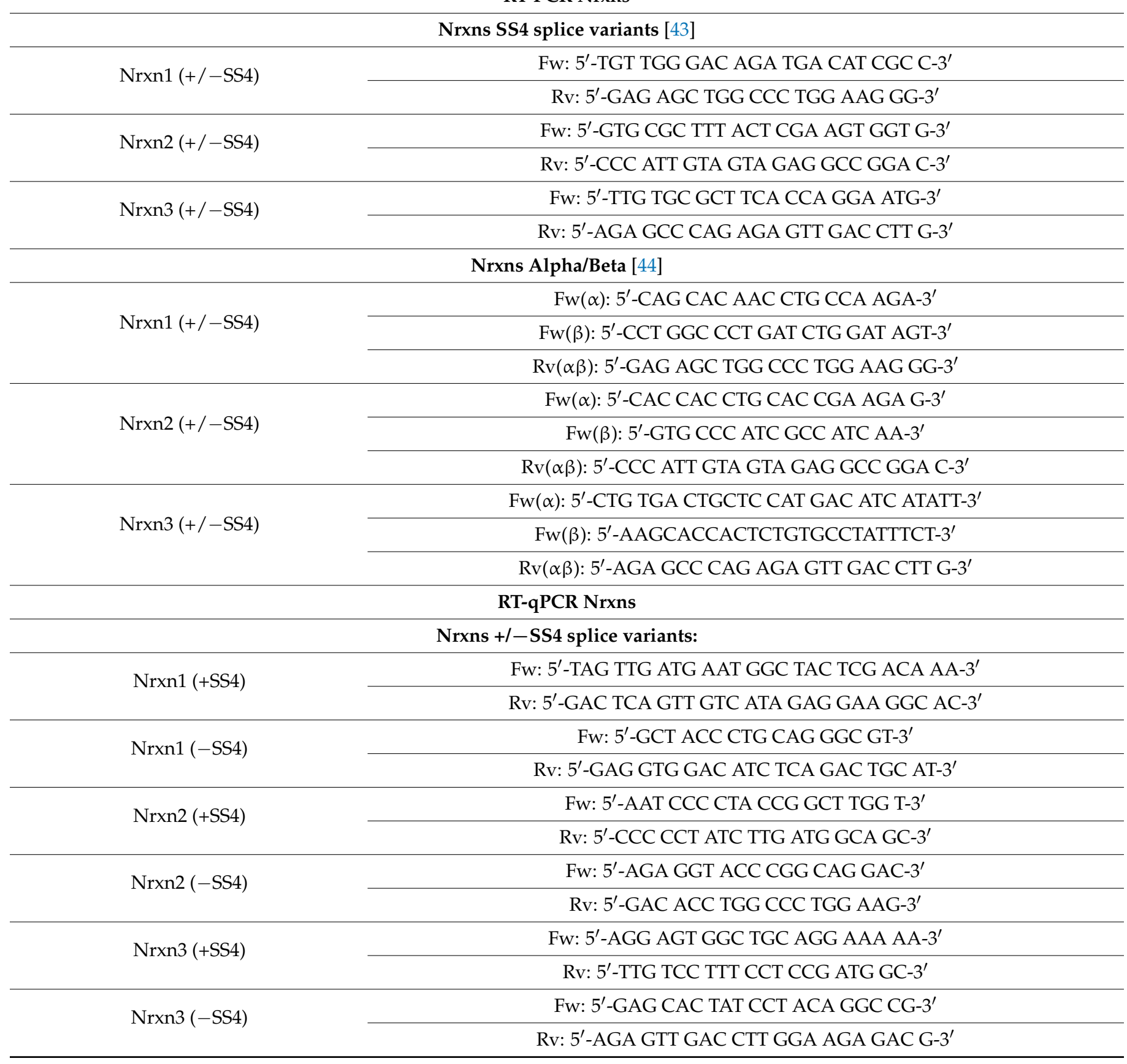


Table 1. Cont.

\section{RT-PCR Nrxns}

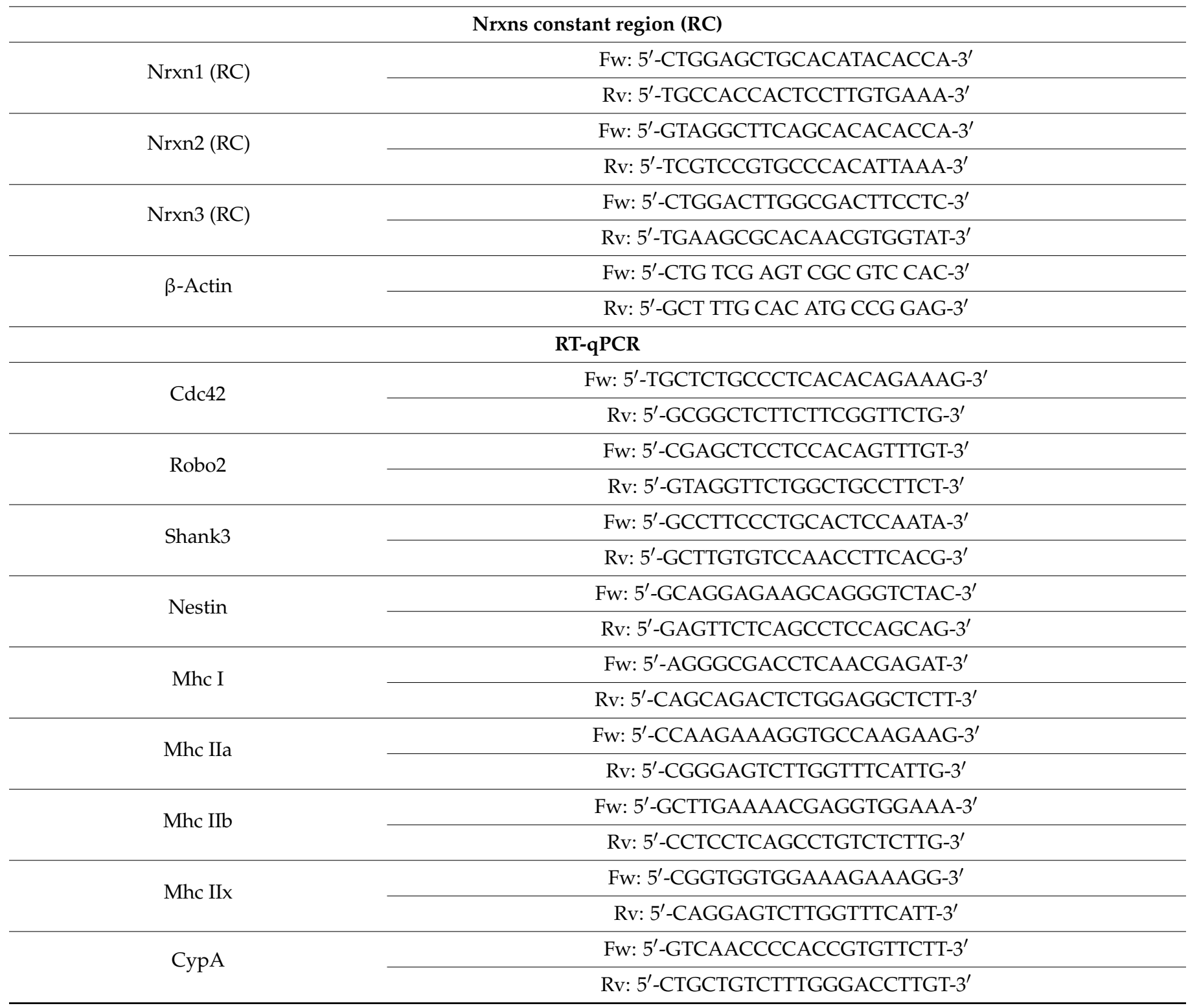

3. Results

3.1. Effect of CP AE on Body Weight, Strength, and Resistance

Mice were trained with CP AE that was characterized by a gradual and progressive increase in intensity, performed three times a week for a total of 12 weeks (see Section 2 and Figure 1A). One-month old mice (P30) were randomly selected and divided in two groups: one group was trained under CP program for 12 weeks, while the corresponding control group was maintained sedentary for 12 weeks (Figure 1B). At the end of training, when mice reached the adult age (P120), physical parameters of trained mice were analyzed and compared to their corresponding sedentary animals. We found that CP training determined an increase in body weight comparable to that of their relative sedentary mice (Figure 1C). In addition, CP training exerted a positive effect on strength, which was significantly increased (Figure 1D), and on resistance, detected as number of falls that were significantly decreased with respect to the sedentary mice (Figure 1E). 


\subsection{CP AE Affects Muscle MyHC Isoform Expression}

Skeletal muscle fibers are capable of adjusting their properties to changes in functional demands [45]. This plasticity correlates with the expression of muscle proteins in various isoform combinations and is impacted by changes in neural activity [46]. To analyze whether $\mathrm{CP}$-trained muscles displayed changes in molecular parameters that determine the structural composition of the fibers, we performed qPCR analysis of RNA isolated from quadriceps. Skeletal muscle fibers can be grouped in one type of slow-twitch fibers (type I) and three types of fast-twitch fibers (type IIa, type IIx/d, and type IIb). Type I and type IIa fibers are oxidative, whereas type IIx and type IIb are primarily glycolytic [47]. Remarkably, $\mathrm{CP}$ AE caused a significant change in myosin heavy chain (MyHC) isoform expression. Specifically, there was a decrease in the expression of MyHC type Ilb $(-35 \% ; p=0.0033)$ and MyHC type IIx $(-30 \% ; p=0.0254)$ glycolytic isoforms (Figure $1 \mathrm{H}, \mathrm{I})$, whereas no significant changes were observed in MyHCI and MyHCIIa expression (Figure 1F,G).

\subsection{CP AE Modulates Neurexin Splicing in FC}

We were interested to investigate if $\mathrm{CP}$ exercise induced molecular changes in two brain regions: FC and hippocampus. FC and hippocampus from the sedentary and the CPtrained mice were isolated and mRNAs were extracted from them, and the expression of Nrxns was analyzed by qPCR. We showed that CP exercise did not induce any modulation in the expression level of Nrxn genes in FC (Figure 2B), while in hippocampus, a slight and significant increase was detected with respect to the sedentary mice (Figure 2A). Then, using specific primers to detect the splice variants at SS4, we showed that $\mathrm{CP}$ exercise induced a significant change of AS of Nrxn1-3 in FC (Figure 2D), but not in hippocampus (Figure 2C). Notably, CP training promoted the SS4 inclusion in FC, determining an increase in SS4+ in all three Nrxns transcripts with respect to the control sedentary animals (fold increase: 1.13 for $N r x n 1,1.26$ for Nrxn2, and 1.12 for Nrxn3 vs. sedentary set as 1). The switch from the exon-skipped transcript (SS4-), present in the sedentary mice, to the exon-included transcript, in the trained mice, was clear for Nrxns 1-2, but less for Nrxn3, since Nrxn3 SS4+ was already the main splice variant expressed in the sedentary animals (Figure 2D). The increase in SS4+ splice variants of all Nrxn genes in FC of the CP-trained mice was further confirmed by qPCR (Figure $2 \mathrm{E}$ ).

Since Nrxn1-3 (SS4+) could belong to $\alpha$ or $\beta$ isoform, we tested which isoform was affected by CP training. RT-PCR analysis using primers specific for either the $\alpha$ or the $\beta$ isoform indicated that the main increase in SS4+ variants was referred to $\alpha$ isoforms for all Nrxns (Figure S1A,B). Nevertheless, a smaller but significant increase in SS4 inclusion in the $\beta$ isoforms of $N r x n 1$ and $N r x n 2$ was also detected (Figure S1A,B), whereas $N r x n 3 \beta$ was already shifted towards the SS4+ in sedentary mice and was not affected by exercise. Collectively, these results indicate that $\mathrm{CP}$ training promoted a shift towards the SS4+ in Nrxn1-2 $\alpha / \beta$ and in Nrxn3 $\alpha$ isoforms, without affecting Nrxn1-3 global expression levels in FC.

\subsection{Neurexin Alternative Splicing in Postnatal Frontal Cortex}

AS is tightly regulated during neurodevelopment, and specific splicing switches accurately define neuronal maturation stages $[48,49]$. To understand if the expression of Nrxn1-3 SS4+ splice variants detected in FC in response of CP exercise could be specifically induced by training and not associated to a specific postnatal brain maturation stage, we investigated the splicing pattern of Nrxn1-3 in FC of mice at different postnatal ages: P30, P75, P120, and P12M. P30 corresponds to the young age when mice started the exercise training, P75 is a young-adult age transition, P120 corresponds to the adult age at which the $\mathrm{CP}$ training ended, and P12M corresponds to a more advanced middle-age stage. We found that the main Nrxn splice variants expressed at young age (P30) were the skipped exon transcripts (SS4-) for all Nrxn genes (Nrxn1-3) (Figure 3A-C). This pattern was maintained unchanged until middle age for Nrxn1-2 (Figure 3A,B), while for Nrxn3, the expression of the exon including splice isoform (SS4+) upregulated from adult age (P120) (Figure 3C). 
This finding indicated that AS of Nrxn1-2 was not modulated during FC maturation, while a change in the expression of Nrxn3 towards SS4+ splice variant occurred at adult age. However, as previously shown (Figure 2D), a further increase in SS4+ Nrxn3 expression following $\mathrm{CP}$ exercise could be detected, suggesting that modulation of AS of all Nrxns induced by exercise was not linked to brain maturation.

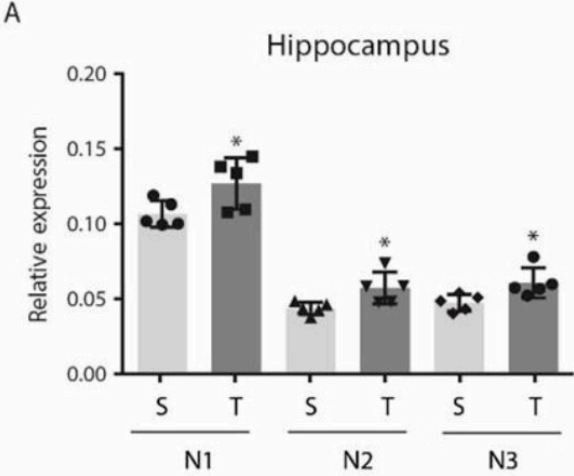

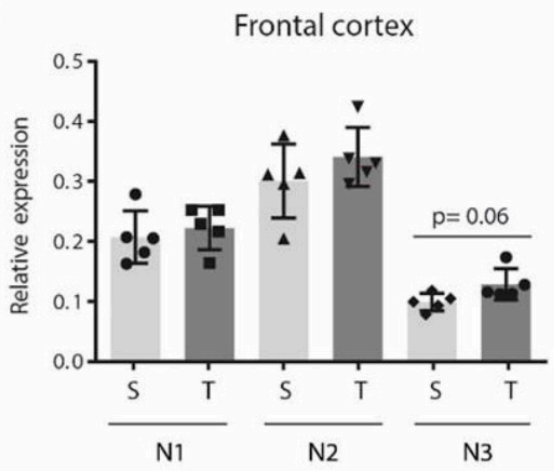

c Hippocampus
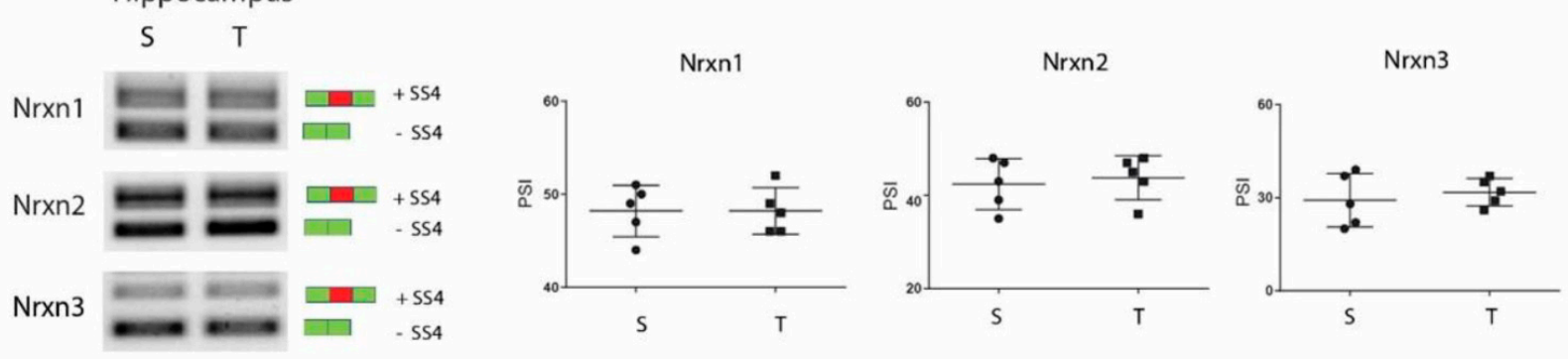

D Frontal cortex $S \quad T$
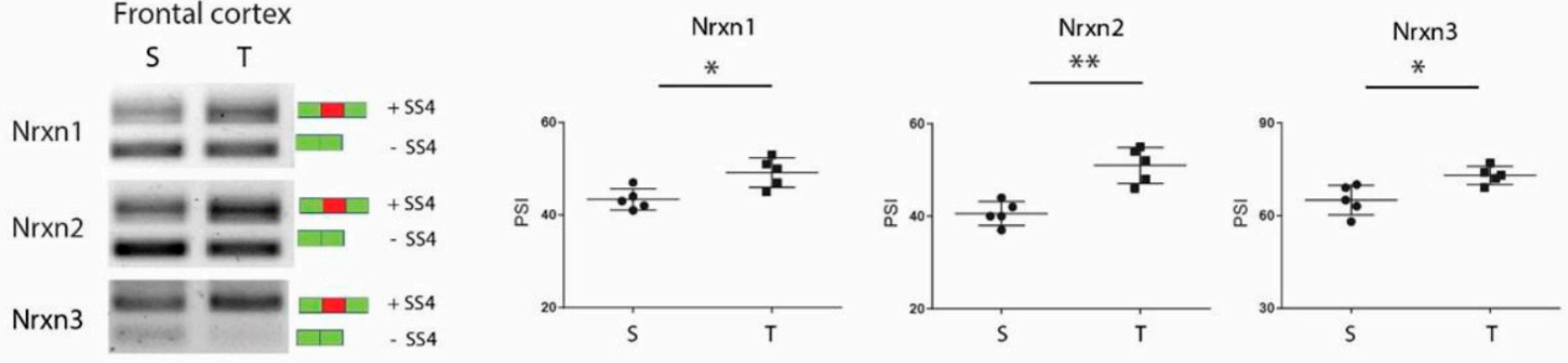

$\mathrm{E}$
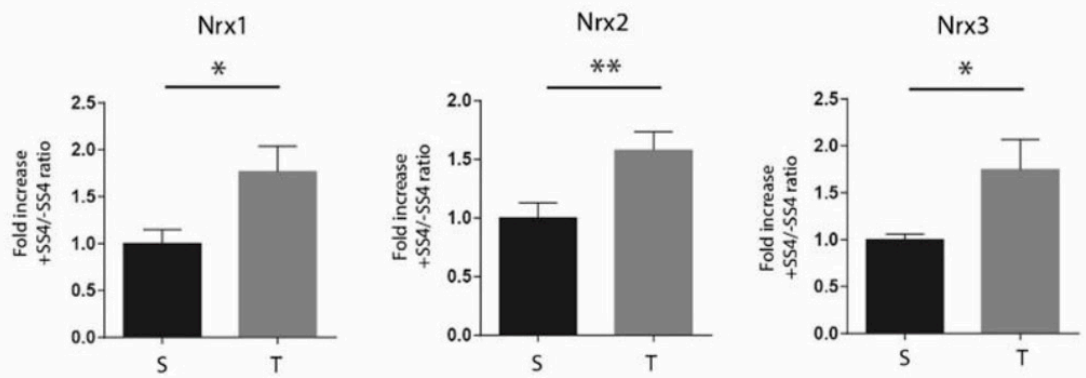

Figure 2. Effect of continuous progressive (CP) exercise on Nrxns splicing in frontal cortex (FC) and hippocampus. Histograms reporting gene expression analysis of total Nrxns (1-3) performed by RT-qPCR, using primers for a constant region, on cDNA from RNA extracted from (A) hippocampus and (B) FC of the sedentary and the CP-trained mice ( $n=5$ per group). $\beta$-Actin is used as reference gene. The expression level of Nrxns increases in hippocampus but not in 
FC following CP exercise. RT-PCR of Nrxns (1-3) alternative splice variants at SS4 in (C) hippocampus and (D) FC of the sedentary and the CP-trained mice. Relative scatter plots (in C,D) show the percent spliced in (PSI) calculated on densitometric values of $n=5$ mice per group. Densitometric analysis was performed using ImageJ-win64. CP protocol induced a significant increase in +SS4 (inclusion) isoform in all 3 Nrxns (Nrxn1 $49.20 \% \pm 1.43$ in T vs. $43.40 \% \pm 1.03$ in $S p=0.0110, \operatorname{Nrnx} 251.00 \% \pm 1.63$ in T vs. $40.60 \% \pm 1.17$ in $S p=0.0001$, and Nrxn3 $73.00 \% \pm 2.17$ in T vs. $65.00 \% \pm 1.45$ in $\mathrm{S} p=0.0087)$. Green box: constitutive splice site. Red box: alternative splice site. Solid circle: sedentary mice. Solid square: trained mice. (E) RT-qPCR on cDNA obtained from RNA extracted from FC of the sedentary and the CP-trained mice ( $n=5$ per group). Histograms report PSI as fold change in the trained mice with respect to the sedentary mice. CP protocol increases the +SS4 isoform in all 3 Nrxns: Nrxn1 $1.77 \pm 0.16$ in T vs. $1 \pm 0.09$ in S $p=0.0131$, Nrxn2 $1.59 \pm 0.10$ in T vs. $1 \pm 0.08$ in S $p=0.0091$, and Nrxn3 $2 \pm 0.17$ in T vs. $1 \pm 0.04$ in S $p=0.0047$ ). The expression of + SS4 isoform is normalized with respect to the $-\mathrm{SS} 4$ isoform. ${ }^{*} p<0.05 ;{ }^{* *} p<0.01$. Error bars represent SD.

A
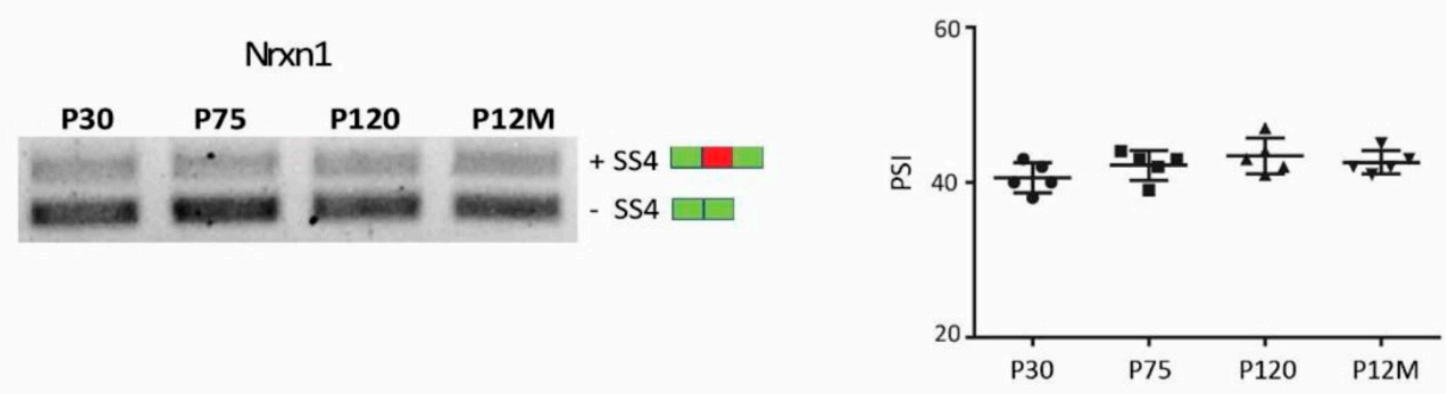

B
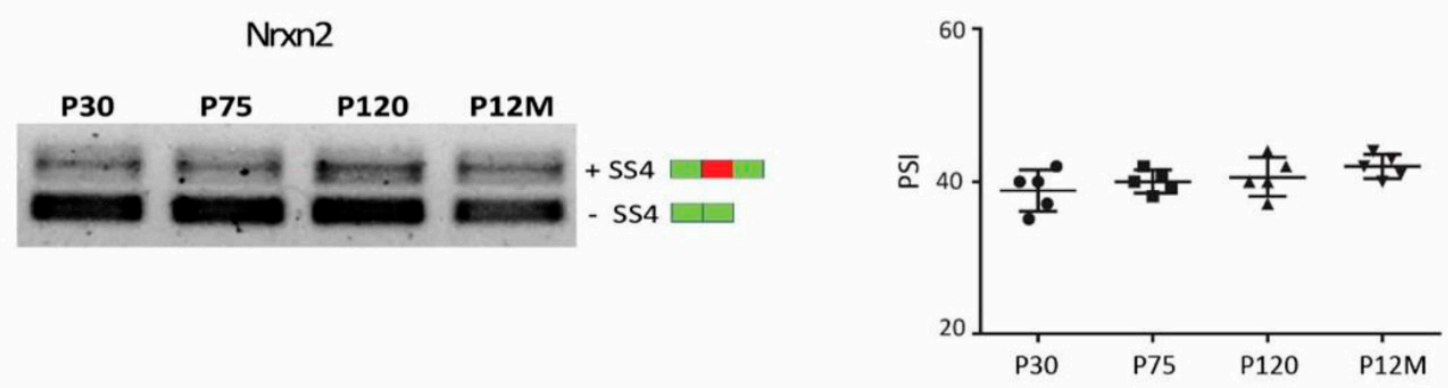

C
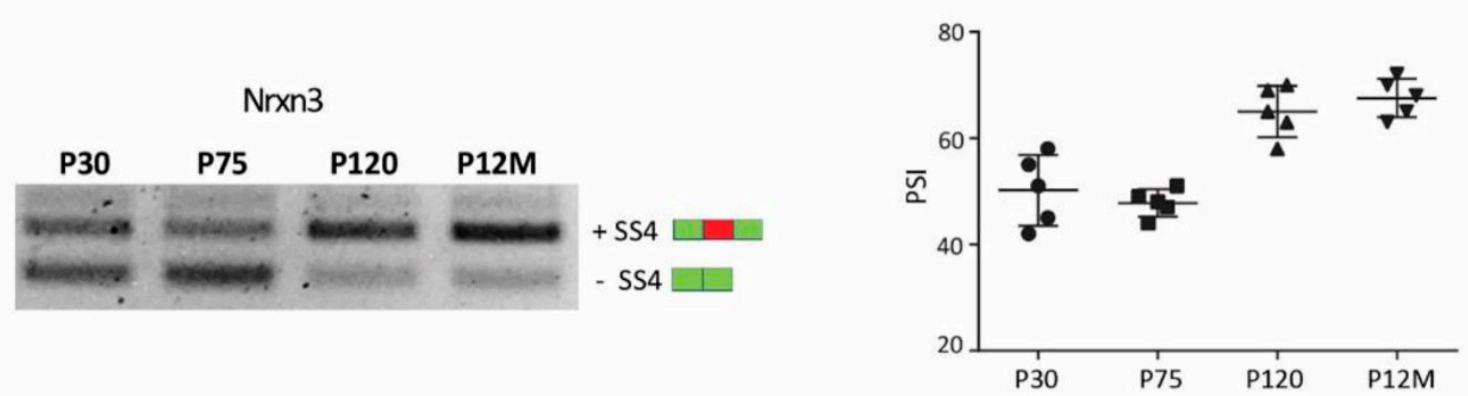

Figure 3. Neurexins splicing pattern in postnatal frontal cortex. RT-PCR analysis of Nrxns splice variants at SS4 in FC of mice at different ages: P30, P75, P120, and P12M ( $n=5$ mice for each group). Representative splicing pattern of Nrxn1 (A) Nrxn2 (B), and Nrxn3 (C). On the right, the corresponding scatter plots shows the densitometric analysis (ImageJ-win64) expressed as PSI (percent spliced in). The splicing pattern for Nrxn1-2 does not change during age, while Nrxn3 shows an increase in the +SS4 isoform from adult age. Statistical analysis was performed by ordinary one-way ANOVA. Error bars represent SD. Green box: constitutive splice site. Red box: alternative splice site.

\subsection{CP AE Modulates Expression of Genes Involved in Synaptic Functions in FC}

To evaluate if modulation of Nrxns AS could be part of a global molecular program induced by $\mathrm{CP}$ training on FC, we investigated the expression of other genes with well- 
established roles in synaptic formation, function, and plasticity, namely, cell division control protein42 (Cdc42), SH3 and multiple Ankyrin repeat domains3 (Shank3), and Roundabout 2 (Robo2). CDC42 is a small guanosine triphosphate hydrolase enzyme (GTPase) of the Ras homologous (Rho) family that regulates initial dendritic formation and dendritic spine maturation at both embryonal and adult age. CDC42 protein plays a role in synaptic plasticity, and genetic ablation of the $C d c 42$ gene leads to deficits in neuronal polarity and elongation of axons in cultured hippocampal neurons as well as in cortical neurons in vivo [50-53]. SHANK3 is a synaptic scaffolding protein that forms a key structural part of the post-synaptic density of excitatory synapses [54]. Expression of Shank3 in a spiny cultured neurons promotes the formation of new synapses, while siRNA-induced knockdown of Shank3 reduces spine densities and increases spine length [55]. The Robo2 gene encodes a receptor with axon guidance functions broadly throughout the nervous system [56], playing essential roles in cell migration, synaptogenesis, synaptic plasticity, neuronal survival, and dendritic patterning during prenatal and early postnatal development [56-59]. By qPCR analysis, we found that expression of all these genes was upregulated in FC with respect to the sedentary controls (Figure 4B) but did not change in hippocampus (Figure 4A). In contrast, the expression of Nestin, a protein expressed by neural progenitor cells (NPCs) [60], was modulated neither in FC nor in hippocampus of the CP-trained mice (Figure 4A,B). These results indicated that molecular changes involved in synaptic plasticity, induced by CP exercise, could be detected only in FC.

\section{Hippocampus}

Cdc42

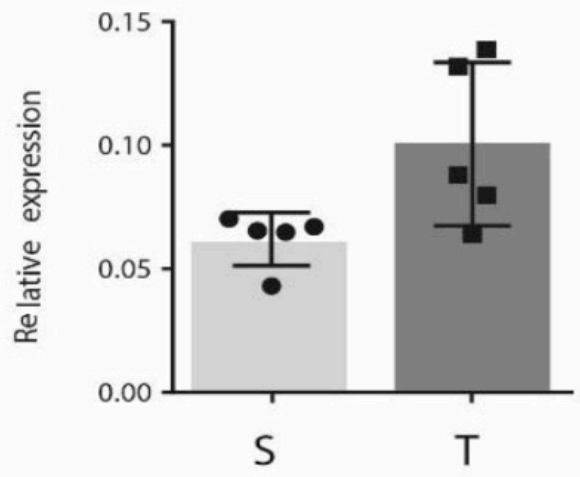

Robo2

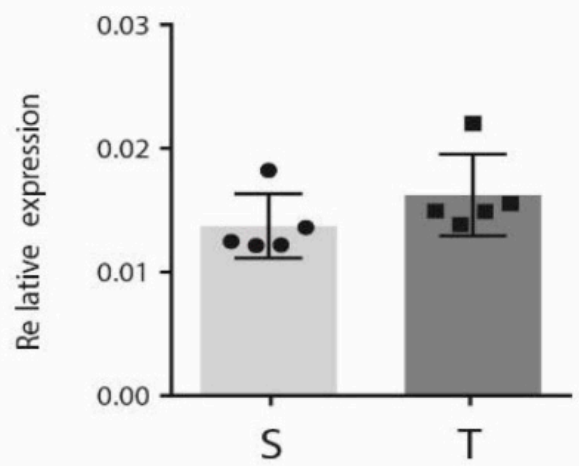

\section{Shank3}

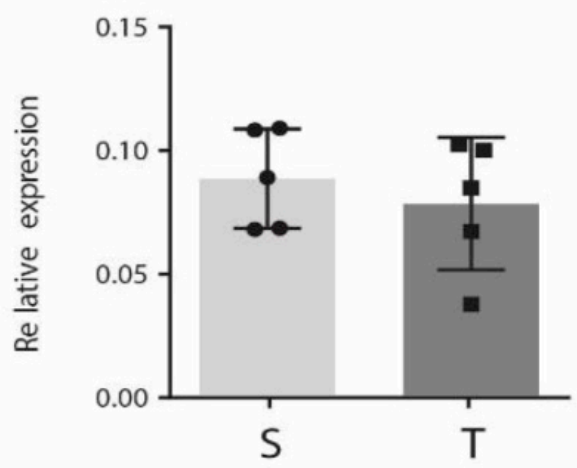

Nestin

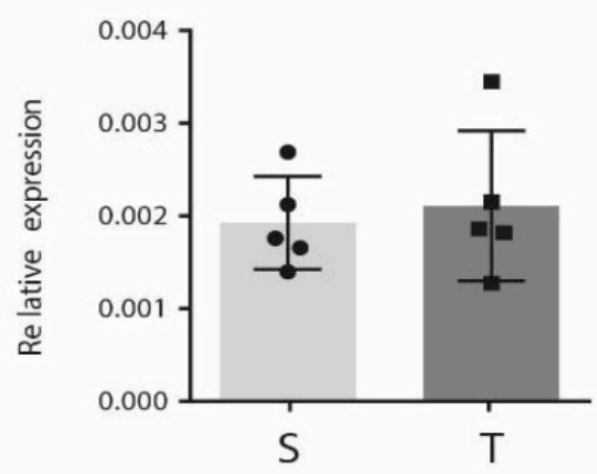

Figure 4. Cont. 
Cdc42

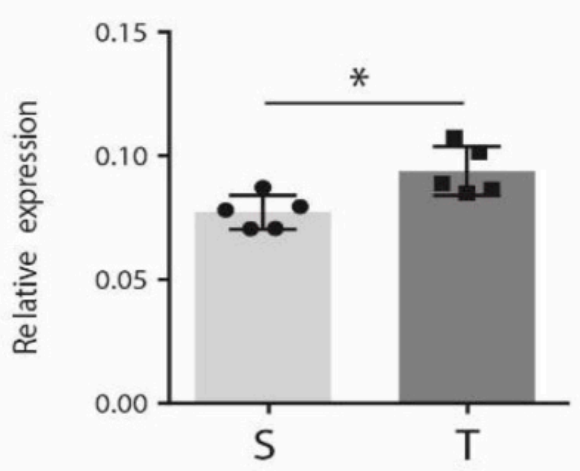

Robo2

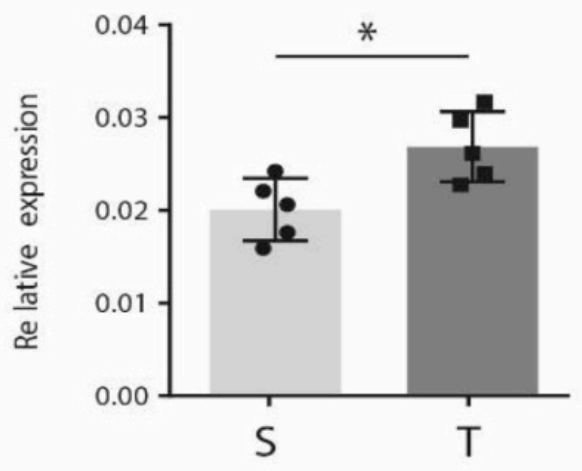

Shank3

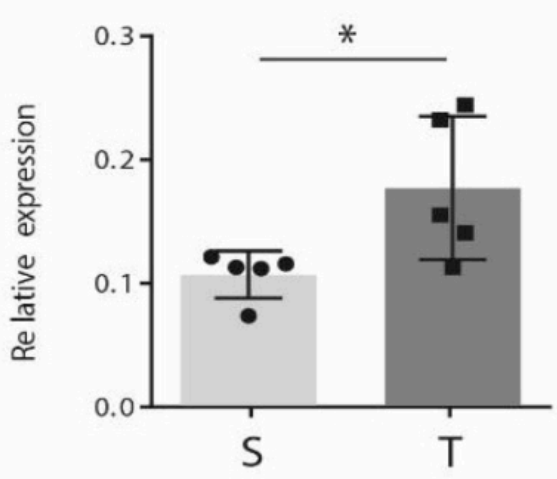

Nestin

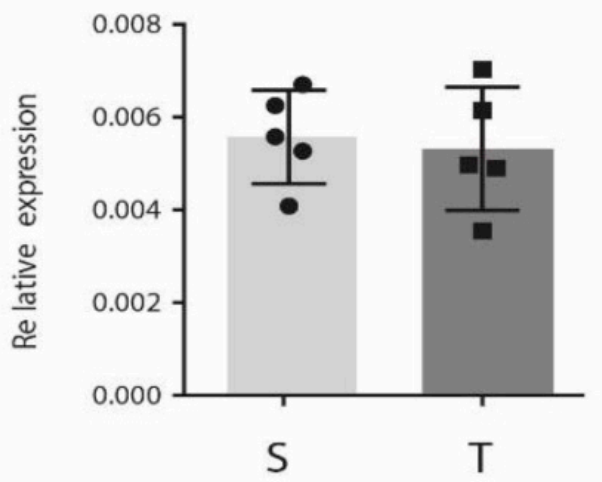

Figure 4. Continuous progressive aerobic exercise (CP AE) modulates gene expression of synaptic-related genes in frontal cortex (FC). Histograms reporting gene expression analysis of Cdc42, Shank3, Robo2, and Nestin analyzed by RT-qPCR on RNA extracted from (A) hippocampus and (B) FC of the sedentary $(n=5)$ and the CP-trained mice $(n=5)$. CP protocol upregulates (Cdc42 $p=0.0153$; Shank3 $p=0.0417$; Robo2 $p=0.0177)$ these genes with respect to the sedentary animals in FC and not in hippocampus. Nestin is not modulated after CP training. $\beta$-actin is used as reference gene. $\left({ }^{*} p<0.05\right)$. Error bars represent SD. Solid circle: sedentary mice. Solid square: trained mice.

\section{Discussion}

Several exercise programs have been used to study the beneficial effects on brain, such as wheel exercise and treadmill exercise of low or high intensity, continuous or intermittent, and of short and long duration [61]. In this study, we trained mice with a continuous progressive aerobic exercise (CP AE) program, which has been previously demonstrated to positively impact on muscle tissues [42]. In this study, we investigated the effect of $\mathrm{CP}$ exercise on brain molecular changes by studying AS of Nrxns. Although Fang et al. [62] previously showed that treadmill exercise exerted a positive effect on $\beta$-Nrxn levels in rat hippocampus; this was the first evidence reporting an effect of exercise on AS of Nrxns. AS is emerged as an important mechanism for the dynamic modification of neuronal functions. Indeed, the expression of specific splice variants can modify signaling properties, synaptic protein functions, and neuronal connectivity [63]. We reported that young mice trained following CP exercise showed increased expression of Nrxn (1-3) splice variants that included the alternative exon at SS4. Moreover, exercise significantly increased the SS4+ splice variant of both $\alpha$ and $\beta$ Nrxn isoforms.

Interestingly, this effect was detected in FC but not in hippocampus, suggesting that FC is possibly a more suitable structure than hippocampus to explore neuronal molecular 
markers as potential improvement of plasticity. Moreover, in line with other previous data, this result suggests that brain molecular changes induced by exercise are not widespread in the brain but exhibit regional specificity [64,65].

We further demonstrated that the exercise-dependent upregulation of SS4+ variants of Nrxns1-3 in FC was not correlated to brain maturation stages, since we did not observe any significant modulation of AS of Nrxn1-2 in the FC of mice from young (P30) to old (P120M) age. As for Nrxn3 expression, it showed a more variable splicing pattern during brain maturation with an increase in SS4+ variant at adult age (P120).

To understand, if Nrxns AS could be part of a more general molecular program of enhancement of brain plasticity, we analyzed the expression of other genes, Cdc42, Shank3 and Robo2, with well-established roles in the synaptic structure and plasticity. We showed that gene expression levels of these genes were upregulated in the CP-trained mice in FC but not in hippocampus. Thus, we conclude that the expression of Nrxns SS4+ splice variants induced by the CP exercise may represent a molecular change by which neuronal cells could modify their synaptic number and strength through interaction with different postsynaptic ligands, improving FC plasticity.

The physiological significance of alternative splice variants of Nrxn1-3 has been partially highlighted up to now. The SS4+ splice variants are known to reduce binding affinity to neuroligins (Nlgns) and to preferentially bind to a class of extracellular ligands called cerebellins $(C b \ln 1-4)[27,66]$. In the hippocampus, the expression of SS4+ splice variants regulates postsynaptic glutamate receptors composition. Dai et al. [67] demonstrated that the SS4+ splice variant of NRXN1 selectively enhanced N-methyl-D-aspartate (NMDA) receptor signaling in the hippocampus, exerting a positive effect on plasticity. Since NMDA, one type of glutamate receptor, is expressed at high density both in hippocampus and in the cortex, we speculate that the increased expression of SS4+ variants of Nrxns1-3 induced by $\mathrm{CP}$ exercise may modulate NMDR receptors signaling and enhance synaptic plasticity in the FC. Accordingly, exercise has been reported to induce modulation of NMDA receptor expression, improving brain plasticity [68].

Using a CP training program, we further demonstrated, at molecular level, the efficacy of this training program in inducing muscular transcriptional and functional changes, with a fast-to-slow transition of muscle fiber transcripts that should result in a faster activation of the mitochondrial oxidative metabolism. These results are in line with previous work documenting a switch from glycolytic to oxidative metabolism upon progressive endurance training in mice [69] and in rats [70,71]. It is well accepted that endurance exercise increases skeletal muscle oxidative capacity by stimulating mitochondrial biogenesis and improving their functional parameters [72,73]. The observed decrease in MyHC IIlb and MyHC IIx transcripts during endurance exercise in quadriceps shows the transformation of muscle contractile apparatus in accordance with the changes of muscle oxidative capacity. The expression of specific contractile isoforms is a relevant mechanism of regulation of heterogeneity and plasticity of skeletal muscle, reflecting the adaptation of the contractile apparatus to the endurance exercise.

In conclusion, we identified AS of Nrxns1-3 as a molecular mechanism modulated by exercise, and we suggest that the expression of specific splice variants of NRXNs may represent new molecular markers by which exercise may improve brain connectivity and plasticity.

Supplementary Materials: The following are available online at https: / www.mdpi.com/article/ 10.3390/jfmk6020048/s1, Figure S1: CP aerobic exercise promotes +SS4 fragment in alpha/beta Nrxns isoforms.

Author Contributions: Conceptualization, G.D., C.S. and P.G.; data curation, E.I., I.C., E.D.D., E.T., V.V. and M.P.P.; writing - original draft preparation, P.G.; writing-review and editing, V.T., M.B. and P.R. All authors have read and agreed to the published version of the manuscript.

Funding: This research received no external funding. 
Institutional Review Board Statement: The study was conducted according to the guidelines of the Declaration of Helsinki and approved by the Ethics Committee of the Interdepartmental Service Centre-Station for Animal Technology (STA)-University of Rome "Tor Vergata", in accordance with national and international laws and policies (Directive 2010/63/EU of the European Parliament and of the Council, Italian Legislative Decree 26/2014).

Informed Consent Statement: Not applicable.

Data Availability Statement: The data presented in this study are available on request from the corresponding authors.

Acknowledgments: This work was supported by the Mission Sustainability GRANT from the University of Rome Tor Vergata (2017).

Conflicts of Interest: The authors declare no conflict of interest.

\section{References}

1. Rovio, S.; Spulber, G.; Nieminen, L.J.; Niskanen, E.; Winblad, B.; Tuomilehto, J.; Nissinen, A.; Soininen, H.; Kivipelto, M. The effect of midlife physical activity on structural brain changes in the elderly. Neurobiol. Aging 2010, 31, 1927-1936. [CrossRef]

2. Voss, M.W.; Heo, S.; Prakash, R.S.; Erickson, K.I.; Alves, H.; Chaddock, L.; Szabo, A.N.; Mailey, E.L.; Wójcicki, T.R.; White, S.M.; et al. The influence of aerobic fitness on cerebral white matter integrity and cognitive function in older adults: Results of a one-year exercise intervention. Hum. Brain Mapp. 2013, 34, 2972-2985. [CrossRef] [PubMed]

3. Voss, M.W.; Vivar, C.; Kramer, A.F.; van Praag, H. Bridging animal and human models of exercise-induced brain plasticity. Trends Cogn. Sci. 2013, 17, 525-544. [CrossRef]

4. Gelfo, F.; Mandolesi, L.; Serra, L.; Sorrentino, G.; Caltagirone, C. The Neuroprotective Effects of Experience on Cognitive Functions: Evidence from Animal Studies on the Neurobiological Bases of Brain Reserve. Neuroscience 2018, 370, $218-235$. [CrossRef] [PubMed]

5. Mandolesi, L.; Polverino, A.; Montuori, S.; Foti, F.; Ferraioli, G.; Sorrentino, P.; Sorrentino, G. Effects of Physical Exercise on Cognitive Functioning and Wellbeing: Biological and Psychological Benefits. Front. Psychol. 2018, 9, 509. [CrossRef]

6. Kramer, A.F.; Hahn, S.; Cohen, N.J.; Banich, M.T.; McAuley, E.; Harrison, C.R.; Chason, J.; Vakil, E.; Bardell, L.; Boileau, R.A.; et al. Ageing, fitness and neurocognitive function. Nature 1999, 400, 418-419. [CrossRef]

7. Colcombe, S.; Kramer, A.F. Fitness effects on the cognitive function of older adults: A meta-analytic study. Psychol. Sci. 2003, 14, 125-130. [CrossRef] [PubMed]

8. $\quad$ Black, J.E.; Isaacs, K.R.; Anderson, B.J.; Alcantara, A.A.; Greenough, W.T. Learning causes synaptogenesis, whereas motor activity causes angiogenesis, in cerebellar cortex of adult rats. Proc. Natl. Acad. Sci. USA 1990, 87, 5568-5572. [CrossRef] [PubMed]

9. Cotman, C.W.; Berchtold, N.C. Exercise: A behavioral intervention to enhance brain health and plasticity. Trends Neurosci. 2002, 25, 295-301. [CrossRef]

10. Griffin, É.W.; Mullally, S.; Foley, C.; Warmington, S.A.; O’Mara, S.M.; Kelly, A.M. Aerobic exercise improves hippocampal function and increases BDNF in the serum of young adult males. Physiol. Behav. 2011, 104, 934-941. [CrossRef] [PubMed]

11. Lea-Carnall, C.A.; Trujillo-Barreto, N.J.; Montemurro, M.A.; El-Deredy, W.; Parkes, L.M. Evidence for frequency-dependent cortical plasticity in the human brain. Proc. Natl. Acad. Sci. USA 2017, 114, 8871-8876. [CrossRef] [PubMed]

12. Craig, A.M.; Kang, Y. Neurexin-neuroligin signaling in synapse development. Curr. Opin. Neurobiol. 2007, 17, 43-52. [CrossRef]

13. Südhof, T.C. Neuroligins and neurexins link synaptic function to cognitive disease. Nature 2008, 455, 903-911. [CrossRef] [PubMed]

14. Krueger, D.D.; Tuffy, L.P.; Papadopoulos, T.; Brose, N. The role of neurexins and neuroligins in the formation, maturation, and function of vertebrate synapses. Curr. Opin. Neurobiol. 2012, 22, 412-422. [CrossRef] [PubMed]

15. Ushkaryov, Y.A.; Südhof, T.C. Neurexin III alpha: Extensive alternative splicing generates membrane-bound and soluble forms. Proc. Natl. Acad. Sci. USA 1993, 90, 6410-6414. [CrossRef] [PubMed]

16. Tabuchi, K.; Südhof, T.C. Structure and evolution of neurexin genes: Insight into the mechanism of alternative splicing. Genomics 2002, 79, 849-859. [CrossRef]

17. Schreiner, D.; Nguyen, T.-M.; Russo, G.; Heber, S.; Patrignani, A.; Ahrné, E.; Scheiffele, P. Targeted combinatorial alternative splicing generates brain region-specific repertoires of neurexins. Neuron 2014, 84, 386-398. [CrossRef]

18. Scheckel, C.; Drapeau, E.; Frias, M.A.; Park, C.Y.; Fak, J.; Zucker-Scharff, I.; Kou, Y.; Haroutunian, V.; Ma'ayan, A.; Buxbaum, J.D.; et al. Regulatory consequences of neuronal ELAV-like protein binding to coding and non-coding RNAs in human brain. eLife 2016, 5. [CrossRef]

19. Zhang, X.; Chen, M.H.; Wu, X.; Kodani, A.; Fan, J.; Doan, R.; Ozawa, M.; Ma, J.; Yoshida, N.; Reiter, J.F.; et al. Cell-Type-Specific Alternative Splicing Governs Cell Fate in the Developing Cerebral Cortex. Cell 2016, 166, 1147-1162.e15. [CrossRef]

20. Cao, X.; Tabuchi, K. Functions of synapse adhesion molecules neurexin/neuroligins and neurodevelopmental disorders. Neurosci. Res. 2017, 116, 3-9. [CrossRef]

21. Ichtchenko, K.; Hata, Y.; Nguyen, T.; Ullrich, B.; Missler, M.; Moomaw, C.; Südhof, T.C. Neuroligin 1: A splice site-specific ligand for beta-neurexins. Cell 1995, 81, 435-443. [CrossRef] 
22. Boucard, A.A.; Chubykin, A.A.; Comoletti, D.; Taylor, P.; Südhof, T.C. A splice code for trans-synaptic cell adhesion mediated by binding of neuroligin 1 to alpha- and beta-neurexins. Neuron 2005, 48, 229-236. [CrossRef] [PubMed]

23. Chich, J.F.; Chapuis, C.; Henry, C.; Vidic, J.; Rezaei, H.; Noinville, S. Vesicle permeabilization by purified soluble oligomers of prion protein: A comparative study of the interaction of oligomers and monomers with lipid membranes. J. Mol. Biol. 2010, 397, 1017-1030. [CrossRef] [PubMed]

24. De Wit, J.; Sylwestrak, E.; O’Sullivan, M.L.; Otto, S.; Tiglio, K.; Savas, J.N.; Yates, J.R., 3rd; Comoletti, D.; Taylor, P.; Ghosh, A. LRRTM2 interacts with Neurexin1 and regulates excitatory synapse formation. Neuron 2009, 64, 799-806. [CrossRef] [PubMed]

25. Koehnke, J.; Katsamba, P.S.; Ahlsen, G.; Bahna, F.; Vendome, J.; Honig, B.; Shapiro, L.; Jin, X. Splice form dependence of beta-neurexin/neuroligin binding interactions. Neuron 2010, 67, 61-74. [CrossRef] [PubMed]

26. Siddiqui, T.J.; Pancaroglu, R.; Kang, Y.; Rooyakkers, A.; Craig, A.M. LRRTMs and neuroligins bind neurexins with a differential code to cooperate in glutamate synapse development. J. Neurosci. 2010, 30, 7495-7506. [CrossRef] [PubMed]

27. Uemura, T.; Lee, S.-J.; Yasumura, M.; Takeuchi, T.; Yoshida, T.; Ra, M.; Taguchi, R.; Sakimura, K.; Mishina, M. Trans-synaptic interaction of GluRdelta2 and Neurexin through Cbln1 mediates synapse formation in the cerebellum. Cell 2010, 141, 1068-1079. [CrossRef]

28. Matsuda, K.; Yuzaki, M. Cbln family proteins promote synapse formation by regulating distinct neurexin signaling pathways in various brain regions. Eur. J. Neurosci. 2011, 33, 1447-1461. [CrossRef]

29. Ehrmann, I.; Gazzara, M.R.; Pagliarini, V.; Dalgliesh, C.; Kheirollahi-Chadegani, M.; Xu, Y.; Cesari, E.; Danilenko, M.; Maclennan, M.; Lowdon, K.; et al. A SLM2 Feedback Pathway Controls Cortical Network Activity and Mouse Behavior. Cell Rep. 2016, 17, 3269-3280. [CrossRef]

30. Traunmüller, L.; Gomez, A.M.; Nguyen, T.-M.; Scheiffele, P. Control of neuronal synapse specification by a highly dedicated alternative splicing program. Science 2016, 352, 982-986. [CrossRef]

31. Ullrich, B.; Ushkaryov, Y.A.; Südhof, T.C. Cartography of neurexins: More than 1000 isoforms generated by alternative splicing and expressed in distinct subsets of neurons. Neuron 1995, 14, 497-507. [CrossRef]

32. Ichtchenko, K.; Nguyen, T.; Südhof, T.C. Structures, alternative splicing, and neurexin binding of multiple neuroligins. J. Biol. Chem. 1996, 271, 2676-2682. [CrossRef]

33. Ehrmann, I.; Dalgliesh, C.; Liu, Y.; Danilenko, M.; Crosier, M.; Overman, L.; Arthur, H.M.; Lindsay, S.; Clowry, G.J.; Venables, J.P.; et al. The tissue-specific RNA binding protein T-STAR controls regional splicing patterns of neurexin pre-mRNAs in the brain. PLoS Genet. 2013, 9, e1003474. [CrossRef] [PubMed]

34. Treutlein, B.; Gokce, O.; Quake, S.R.; Südhof, T.C. Cartography of neurexin alternative splicing mapped by single-molecule long-read mRNA sequencing. Proc. Natl. Acad. Sci. USA 2014, 111, E1291-E1299. [CrossRef] [PubMed]

35. Shapiro-Reznik, M.; Jilg, A.; Lerner, H.; Earnest, D.J.; Zisapel, N. Diurnal rhythms in neurexins transcripts and inhibitory/excitatory synapse scaffold proteins in the biological clock. PLoS ONE 2012, 7, e37894. [CrossRef]

36. Jenkins, A.K.; Paterson, C.; Wang, Y.; Hyde, T.M.; Kleinman, J.E.; Law, A.J. Neurexin 1 (NRXN1) splice isoform expression during human neocortical development and aging. Mol. Psychiatry 2016, 21, 701-706. [CrossRef]

37. Patzke, H.; Ernsberger, U. Expression of neurexin Ialpha splice variants in sympathetic neurons: Selective changes during differentiation and in response to neurotrophins. Mol. Cell. Neurosci. 2000, 15, 561-572. [CrossRef]

38. Zeng, Y.; Zhao, D.; Xie, C.-W. Neurotrophins enhance CaMKII activity and rescue amyloid- $\beta$-induced deficits in hippocampal synaptic plasticity. J. Alzheimers Dis. 2010, 21, 823-831. [CrossRef]

39. Rozic, G.; Lupowitz, Z.; Piontkewitz, Y.; Zisapel, N. Dynamic changes in neurexins' alternative splicing: Role of Rho-associated protein kinases and relevance to memory formation. PLOS ONE 2011, 6, e18579. [CrossRef]

40. Fuccillo, M.V.; Földy, C.; Gökce, Ö.; Rothwell, P.E.; Sun, G.L.; Malenka, R.C.; Südhof, T.C. Single-Cell mRNA Profiling Reveals Cell-Type-Specific Expression of Neurexin Isoforms. Neuron 2015, 87, 326-340. [CrossRef]

41. Cariati, I.; Scimeca, M.; Tancredi, V.; D’Amico, A.G.; Pallone, G.; Palmieri, M.; Frank, C.; D’Arcangelo, G. Effects of different continuous aerobic training protocols in a heterozygous mouse model of Niemann-Pick type C disease. J. Funct. Morphol. Kinesiol. 2020, 5, 53. [CrossRef]

42. Pallone, G.; Palmieri, M.; Cariati, I.; Bei, R.; Masuelli, L.; D'arcangelo, G.; Tancredi, V. Different continuous training modalities result in distinctive effects on muscle structure, plasticity and function. Biomed. Rep. 2020, 12. [CrossRef]

43. Iijima, T.; Wu, K.; Witte, H.; Hanno-Iijima, Y.; Glatter, T.; Richard, S.; Scheiffele, P. SAM68 regulates neuronal activity-dependent alternative splicing of neurexin-1. Cell 2011, 147, 1601-1614. [CrossRef]

44. Nguyen, T.-M.; Schreiner, D.; Xiao, L.; Traunmüller, L.; Bornmann, C.; Scheiffele, P. An alternative splicing switch shapes neurexin repertoires in principal neurons versus interneurons in the mouse hippocampus. eLife 2016, 5. [CrossRef] [PubMed]

45. Pette, D.; Staron, R.S. Mammalian skeletal muscle fiber type transitions. Int. Rev. Cytol. 1997, 170, 143-223. [CrossRef] [PubMed]

46. Gunning, P.; Hardeman, E. Multiple mechanisms regulate muscle fiber diversity. FASEB J. 1991, 5, 3064-3070. [CrossRef] [PubMed]

47. Schiaffino, S.; Reggiani, C. Fiber types in mammalian skeletal muscles. Physiol. Rev. 2011, 91, 1447-1531. [CrossRef]

48. Weyn-Vanhentenryck, S.M.; Feng, H.; Ustianenko, D.; Duffié, R.; Yan, Q.; Jacko, M.; Martinez, J.C.; Goodwin, M.; Zhang, X.; Hengst, U.; et al. Precise temporal regulation of alternative splicing during neural development. Nat. Commun. 2018, 9, 2189. [CrossRef] [PubMed] 
49. Farini, D.; Cesari, E.; Weatheritt, R.J.; La Sala, G.; Naro, C.; Pagliarini, V.; Bonvissuto, D.; Medici, V.; Guerra, M.; Di Pietro, C.; et al. A Dynamic Splicing Program Ensures Proper Synaptic Connections in the Developing Cerebellum. Cell Rep. 2020, $31,107703$. [CrossRef]

50. Schwamborn, J.C.; Püschel, A.W. The sequential activity of the GTPases Rap1B and Cdc42 determines neuronal polarity. Nat. Neurosci. 2004, 7, 923-929. [CrossRef]

51. Nishimura, T.; Yamaguchi, T.; Kato, K.; Yoshizawa, M.; Nabeshima, Y.; Ohno, S.; Hoshino, M.; Kaibuchi, K. PAR-6-PAR-3 mediates Cdc42-induced Rac activation through the Rac GEFs STEF/Tiam1. Nat. Cell Biol. 2005, 7, 270-277. [CrossRef]

52. Garvalov, B.K.; Flynn, K.C.; Neukirchen, D.; Meyn, L.; Teusch, N.; Wu, X.; Brakebusch, C.; Bamburg, J.R.; Bradke, F. Cdc42 regulates cofilin during the establishment of neuronal polarity. J. Neurosci. 2007, 27, 13117-13129. [CrossRef] [PubMed]

53. Kim, I.H.; Wang, H.; Soderling, S.H.; Yasuda, R. Loss of Cdc42 leads to defects in synaptic plasticity and remote memory recall. eLife 2014, 3. [CrossRef]

54. Kreienkamp, H.-J. Scaffolding proteins at the postsynaptic density: Shank as the architectural framework. Handb. Exp. Pharmacol. 2008, 365-380. [CrossRef]

55. Wang, X.; McCoy, P.A.; Rodriguiz, R.M.; Pan, Y.; Je, H.S.; Roberts, A.C.; Kim, C.J.; Berrios, J.; Colvin, J.S.; Bousquet-Moore, D.; et al. Synaptic dysfunction and abnormal behaviors in mice lacking major isoforms of Shank3. Hum. Mol. Genet. 2011, 20, 3093-3108. [CrossRef] [PubMed]

56. Ypsilanti, A.R.; Chedotal, A. Roundabout receptors. Adv. Neurobiol. 2014, 8, 133-164. [CrossRef]

57. Shen, K.; Cowan, C.W. Guidance molecules in synapse formation and plasticity. Cold Spring Harb. Perspect. Biol. 2010, 2, a001842. [CrossRef]

58. Gibson, E.M.; Purger, D.; Mount, C.W.; Goldstein, A.K.; Lin, G.L.; Wood, L.S.; Inema, I.; Miller, S.E.; Bieri, G.; Zuchero, J.B.; et al. Neuronal activity promotes oligodendrogenesis and adaptive myelination in the mammalian brain. Science 2014, 344,1252304 . [CrossRef]

59. Koropouli, E.; Kolodkin, A.L. Semaphorins and the dynamic regulation of synapse assembly, refinement, and function. Curr Opin. Neurobiol. 2014, 27, 1-7. [CrossRef]

60. Hendrickson, M.L.; Rao, A.J.; Demerdash, O.N.A.; Kalil, R.E. Expression of nestin by neural cells in the adult rat and human brain. PLoS ONE 2011, 6, e18535. [CrossRef]

61. Ferreira, A.F.B.; Real, C.C.; Rodrigues, A.C.; Alves, A.S.; Britto, L.R.G. Moderate exercise changes synaptic and cytoskeletal proteins in motor regions of the rat brain. Brain Res. 2010, 1361, 31-42. [CrossRef]

62. Fang, Z.H.; Lee, C.H.; Seo, M.K.; Cho, H.; Lee, J.G.; Lee, B.J.; Park, S.W.; Kim, Y.H. Effect of treadmill exercise on the BDNFmediated pathway in the hippocampus of stressed rats. Neurosci. Res. 2013, 76, 187-194. [CrossRef]

63. Raj, B.; Blencowe, B.J. Alternative Splicing in the Mammalian Nervous System: Recent Insights into Mechanisms and Functional Roles. Neuron 2015, 87, 14-27. [CrossRef]

64. Basso, J.C.; Shang, A.; Elman, M.; Karmouta, R.; Suzuki, W.A. Acute Exercise Improves Prefrontal Cortex but not Hippocampal Function in Healthy Adults. J. Int. Neuropsychol. Soc. 2015, 21, 791-801. [CrossRef]

65. Cefis, M.; Prigent-Tessier, A.; Quirié, A.; Pernet, N.; Marie, C.; Garnier, P. The effect of exercise on memory and BDNF signaling is dependent on intensity. Brain Struct. Funct. 2019, 224, 1975-1985. [CrossRef]

66. Ito-Ishida, A.; Miyazaki, T.; Miura, E.; Matsuda, K.; Watanabe, M.; Yuzaki, M.; Okabe, S. Presynaptically released Cbln1 induces dynamic axonal structural changes by interacting with GluD2 during cerebellar synapse formation. Neuron 2012, 76, 549-564. [CrossRef] [PubMed]

67. Dai, J.; Aoto, J.; Südhof, T.C. Alternative Splicing of Presynaptic Neurexins Differentially Controls Postsynaptic NMDA and AMPA Receptor Responses. Neuron 2019, 102, 993.e5-1008.e5. [CrossRef] [PubMed]

68. Park, J.-K.; Lee, S.-J.; Kim, T.-W. Treadmill exercise enhances NMDA receptor expression in schizophrenia mice. J. Exerc. Rehabil. 2014, 10, 15-21. [CrossRef]

69. Holloszy, J.O. Biochemical adaptations in muscle. Effects of exercise on mitochondrial oxygen uptake and respiratory enzyme activity in skeletal muscle. J. Biol. Chem. 1967, 242, 2278-2282. [CrossRef]

70. Fitts, R.H.; Booth, F.W.; Winder, W.W.; Holloszy, J.O. Skeletal muscle respiratory capacity, endurance, and glycogen utilization. Am. J. Physiol. 1975, 228, 1029-1033. [CrossRef]

71. Davies, K.J.; Packer, L.; Brooks, G.A. Biochemical adaptation of mitochondria, muscle, and whole-animal respiration to endurance training. Arch. Biochem. Biophys. 1981, 209, 539-554. [CrossRef]

72. Hood, D.A. Mechanisms of exercise-induced mitochondrial biogenesis in skeletal muscle. Appl. Physiol. Nutr. Metab. 2009, 34, 465-472. [CrossRef] [PubMed]

73. Ljubicic, V.; Joseph, A.-M.; Saleem, A.; Uguccioni, G.; Collu-Marchese, M.; Lai, R.Y.J.; Nguyen, L.M.-D.; Hood, D.A. Transcriptional and post-transcriptional regulation of mitochondrial biogenesis in skeletal muscle: Effects of exercise and aging. Biochim. Biophys. Acta 2010, 1800, 223-234. [CrossRef] [PubMed] 